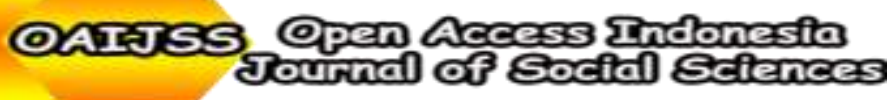

Open Access Indonesia Journal of Social Sciences Volume 1, Issue 2, Page No: 13-24

Available online: www.journalsocialsciences.com

OAIJSS 1(2):13-24

\section{Implementation of East Ogan Komering Ulu Regent Regulation Number 17 of 2015 \\ Regarding Technical Guidelines for Implementing Micro and Small Business Permits}

Nety Andriani ${ }^{1}$, Slamet Widodo ${ }^{1}$, and Andy Alfatih ${ }^{1 *}$

${ }^{1}$ Faculty of Social and Political Sciences - Sriwijaya University

* Corresponding Author Email: andy.alfatih20@gmail.com

\begin{abstract}
The purpose of this research is to find out how the implementation of East Ogan Komering Ulu (OKU) Regency Regulation Number 17 of 2015 regarding Technical Guidelines for Micro and Small Business Permits in three sub-districts in East OKU Regency and also to find out the factors that support and hinder the implementation of policies. The policy implementation is analyzed using three variables; the level of compliance, wellfunctioning routines, and the absence of problems, and the desired performance and impact of the policies implemented. The results showed that East OKU Regency Regulation No. 17 of 2015 concerning Technical Guidelines for Micro and Small Business Permits in three districts in East OKU Regency has not been implemented optimally. This is indicated by some costs that entrepreneurs must pay when they want to get a license, micro and small licensing processes that have been done in real time, reports on the implementation of micro and small licenses that have not been done by the district, and supervision from the Office of Cooperatives and Small and Medium Enterprises is not fully done. In line with that, the researchers found the factors that supported the successful implementation of the policy were efforts to take a license application from employers and the achievement of delivery time. While the factors that hinder the successful implementation of this policy are the unavailability of the budget, lack of infrastructure and working equipment, uneven network and internet connections, and lack of coordination. Therefore, improvements need to be made by meeting the resources needed, and also to maximize training and supervision of the implementation of micro and small licenses by the Office of Cooperatives and Small and Medium Enterprises.
\end{abstract}




\section{OAI SSS Qpen Access Indonesta}

Keywords: implementation of policies, micro and small business , technical guidelines

\section{Introduction}

Around $1.65 \%$ of the total population of Indonesia, are entrepreneurs / business actors and Micro and Small Business Actors (PUMK) in Indonesia are business operators with the largest percentage, reaching above $90 \%$ of the total national business actors. Thus, these micro and small businesses are basically the businesses that absorb the most labor, even it is estimated that around $97 \%$ of the total workforce is absorbed by Micro, Small and Medium Enterprises / MSMEs, so that most directly intersect with the level of community welfare (Alkib, 2010).

The government also supports the development of Micro and Small Enterprises in Indonesia, one of which is by issuing regulations in the form of Law 20 of 2008 concerning Micro, Small and Medium Enterprises, then in the era of President Susilo Bambang Yudhoyono President Regulation No. 98 of 2014 concerning Licensing for Micro and Small Enterprises then followed the Minister of Domestic Affairs Regulation No. 83 of 2014 concerning Guidelines for Granting Micro and Small Business Licenses.

With the spirit to improve the economy in East OKU Regency, which in the end is expected to contribute to income distribution and poverty reduction, through ease in obtaining business licenses, then on April 2015, the East OKU Regent issued Regents Regulation No. 17 of 2015 concerning Technical Guidelines for Implementing Micro and Small Business Permits. Hopefully, with the implementation of the Regulation Regent, PUMK in East OKU Regency will have completed one of the requirements in obtaining credit access to financial institutions to increase capital and business productivity, namely business licenses.

An indication of the implementation of the issuance of IUMK that is not in accordance with official procedures, is one of the concerns in the implementation of the Regulation. This illustrates that there are still obstacles to the East OKU Regent's Regulation Number 17 Year 2015 regarding Technical Guidelines for the Implementation of Micro and Small Business Permits in implementing the policy, which can be seen from various problems encountered including the low level of socialization regarding the issuance of IUMK, the low understanding of related employees IUMK, the unavailability of IUMK publishing resources, lack of budget support, lack of adequate infrastructure and support. 


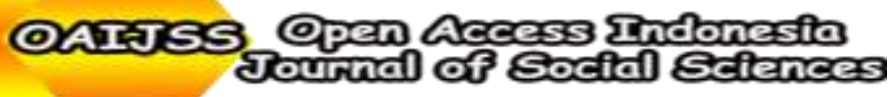

From the description of the above problems, and seeing the implementation of IUMK issuance which is still relatively new in the District in East OKU District, the writer is interested in further researching the implementation of IUMK issuance in the East OKU Regency. The research plan to be carried out is entitled "Implementation of East OKU Regent Regulation Number 17 Year 2015 concerning Technical Guidelines for Implementing Micro and Small Business Permits".

\section{Literature Review}

There are various perspectives in interpreting the term public insight / public policy. Referring to the concept of policy, Nugroho (2014: 129), said that public insight is formed from two words: policy and public. Policy (policy) is an authoritative decision, a decision made by someone who holds an authority, formal or informal (an authoritative decision. Decision made by the one who holds the authority, formal or informal). Whereas 'public' is a group of people who are bound by a particular issue. So, the 'public' is not the public, the people, the community, or just stakeholders. The public is also an environment where people become citizens, a space where citizens interact, where the state and society exist (a sphere where people become citizens, a space where citizens interact, where the state and society exist). So, it can simply be said that public policy is any decision made by the state, as a strategy to realize the goals of a country. Public policy is a strategy to deliver the community at an early stage, to later enter the transition period, and towards the aspired people (Alfatih 2010; Anderson, 2003; Dunn, 2003; Dye, 2013; Edward, 1980; Grindle, 1980; Nugroho, 2014)

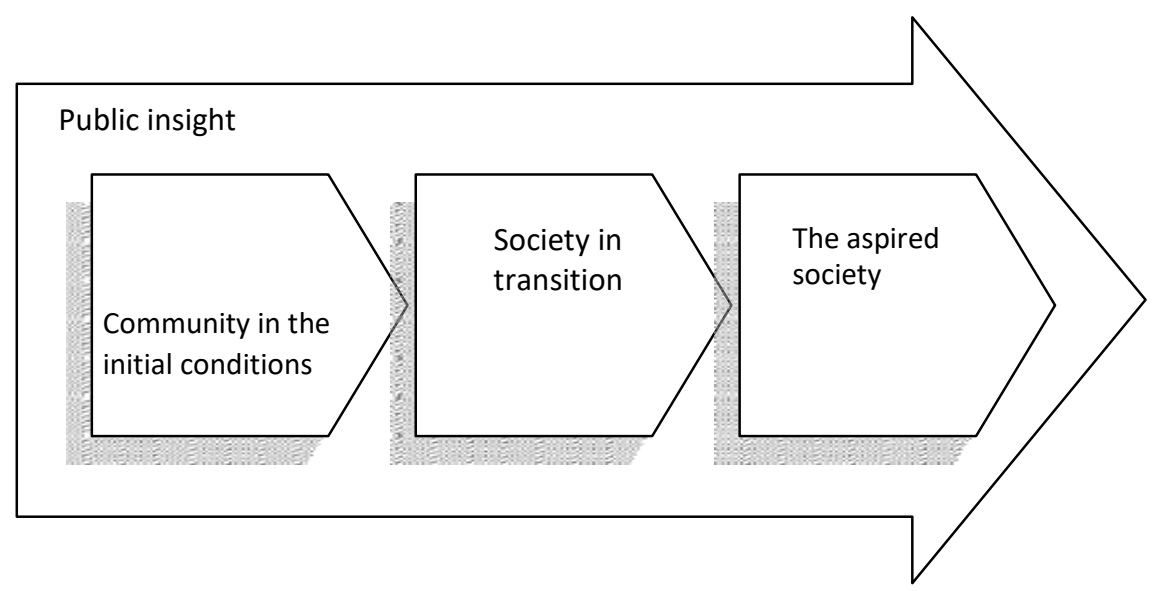

Figure 1. Ideal Public Policy (Nugroho, 2014: 129) 


\section{OAI SSS Qpen Access Indonesta}

In principle, the factors that influence the Implementation of the East OKU Regent's Regulation Number 17 of 2015 concerning Technical Guidelines for the Implementation of Micro and Small Business Permits, have not yet been determined, and can only be known when researching in the field. Theoretically, according to George C. Edward III (1980) in his book "Implementing Public Policy" that the study of policy implementation begins with an overview and questions about what are the requirements for successful implementation and what are the main obstacles to successful policy implementation. To answer this, Edward III (1980: 9-10) revealed that to answer these obstacles was done by considering four critical factors or variables in implementing a public policy namely: communication, resources, disposition / attitude of the apparatus and the structure of the bureaucracy. ("to answer these important questions by considering four critical factors or variables in implementing public policy: communication, resources, dispositions or attitudes, and bureaucratic structure ").

In this study, the factors that influence the implementation of IUMK issuance are not necessarily the same as those presented by George C. Edward III. However, Edward II's theory can provide an overview of the factors that influence the implementation of a policy. Factors that factually support and hinder the implementation of the IUMK issuance policy will be found (Richardson, 2004; Ripley, 1986; Thoha, 2008; Hayubi, 2016; Jahanshahi, 2011; Julita, 2017; Nadela, 2017; Raselawati, 2011; Saputra, 2015; Weaver, 2009).

\section{Methods}

The focus of the study is the Implementation of the East OKU Regent's Regulation Number 17 of 2015 concerning Technical Guidelines for the Implementation of Micro and Small Business Permits and the factors that support and hinder their implementation. The focus of research in implementing policies according to Ripley and Franklin in this study are: The level of compliance with regulations, the smooth functioning of routines, and the realization of the desired performance and impact.

Researchers will explore information by in-depth interviews from informants who have been established or known as purposive sampling. In this study, informants can be divided into key informants and supporting informants. In this case, the key informant is the implementor in East OKU Regency and its instruments, especially those who have the main tasks and functions of serving the issuance of micro and small business licenses. There are 20 (twenty) people in East OKU Regency. 


\section{OAI SSS Qpen Access Indonesta}

Unit of analysis is a unit of individuals, groups, objects or a screen of social events to be examined or analyzed. As for the unit of analysis in this study are the organizations involved in the Implementation of the East OKU Regent's Regulation Number 17 Year 2015 regarding Technical Guidelines for the Implementation of Micro and Small Business Permits, namely: Buay Madang Timur District, Madang Suku II Subdistrict and Buay Madang District, and individuals namely business actors utilizing IUMK publishing services in East OKU Regency.

Data by type can be in the form of qualitative data and quantitative data. Qualitative data were obtained from interviews with informants in Buay Madang Timur District, Madang Suku II Subdistrict, Buay Madang District, Cooperative and SME Office, and Regional Inspectorate, as well as other data in the form of information obtained from books, reports, regulations legislation related to the implementation of IUMK publishing, data available on the page www.iumk.bri.co.id, website or news from the internet, and related research. While quantitative data obtained from books or reports related to numbers (statistical data).

The data sources are primary data and secondary data. Primary data is data obtained directly from data sources and secondary data is supporting data relating to the subject matter of research in nature which complements and strengthens primary data. Data collection techniques used in this study are: observation, interviews, documentation, and audio-visual material. The analysis technique used in this study is a qualitative analysis technique. The stages in data analysis are data reduction, data display and conclusion drawing / verification.

The concept definition of this research is: Public policy in this study is the Regulation of the East OKU Regent No. 17 of 2015 concerning Technical Guidelines for the Implementation of Micro and Small Business Permits. The implementation of the policy in this study is the implementation or application of Regent's Regulation Number 17 Year 2015 concerning Technical Guidelines for Implementing Micro and Small Business Permits. Micro and Small Business License (IUMK) is a type of business licensing granted to Micro and Small Business Actors (PUMK). The level of compliance is: Subdistrict obedience as an implementor in implementing IUMK implementation service procedures in accordance with the Regulation of the East OKU Regent No. 17 of 2015 concerning Technical Guidelines for the Implementation of Micro and Small Business Permits, the Cooperative and SME Office of East OKU Regency in carrying out guidance and supervision of the implementation of IUMK. Obedience of the target group, namely PUMK in managing IUMK. The smooth functioning of routine is the availability of working tools, the availability of human resources, and the 


\section{OAI SSS Qpen Access Indonesta}

establishment of inter-line communication in the implementation of IUMK. The desired performance is to increase IUMK issuance and to realize synchronization of IUMK implementation data in the field and on the website. The desired impact is the creation of free, simple, easy and fast IUMK services, increased PUMK income and the use of a database on PUMK for development planning.

\section{Results and Discussion}

In reviewing the implementation of East OKU Regent's Regulation Number 17 Year 2015 regarding Technical Guidelines for the Implementation of Micro and Small Business Permits in three sub-districts in East OKU Regency, the writer will begin discussion of indicators for each dimension.

The compliance level dimension consists of 3 (three) indicators, namely a) compliance with IUMK implementation service procedures, b) compliance with the guidance and supervision of IUMK implementation, and c) target group compliance, as shown in table 1.

Table 1. Research results related to compliance

\begin{tabular}{|c|c|}
\hline Indicator & Result \\
\hline $\begin{array}{l}\text { Compliance with IUMK implementation } \\
\text { service procedures }\end{array}$ & $\begin{array}{l}\text { 1. Issuance of IUMK sometimes exceeds } \\
\text { the specified service deadline, which is } \\
\text { one day } \\
\text { 2. There is still a component of costs } \\
\text { incurred by PUMK when applying for } \\
\text { IUMK }\end{array}$ \\
\hline $\begin{array}{l}\text { Compliance with the guidance and } \\
\text { supervision of the implementation of the } \\
\text { IUMK }\end{array}$ & $\begin{array}{l}\text { 1. IUMK operator performance in } \\
\text { reporting, is still not good. Have never } \\
\text { sent a report on the implementation of } \\
\text { IUMK to the Office of Cooperatives and } \\
\text { SMEs. }\end{array}$ \\
\hline
\end{tabular}




\section{QAImSS Open Access Indonesta}

\begin{tabular}{|l|l|}
\hline \multirow{2}{*}{ Target group compliance } & $\begin{array}{l}\text { 2. Not yet carried out monitoring and } \\
\text { evaluation by the Office related to the } \\
\text { implementation of IUMK. }\end{array}$ \\
\hline $\begin{array}{l}\text { 1. PUMK has not all reported their business } \\
\text { activities to the District Office }\end{array}$ \\
$\begin{array}{l}\text { 2. There are still PUMKs who do not } \\
\text { understand the other benefits of IUMK, } \\
\text { apart from the legal neglect of doing } \\
\text { business }\end{array}$ \\
\hline
\end{tabular}

The dimensions of the smoothness of routine functions consist of 3 (three) indicators, namely a) availability of work tools, b) availability of human resources and c) communication, as shown in table 2

Table 2 Results of research related to routine function

\begin{tabular}{|l|l|}
\hline \multicolumn{1}{|c|}{ Indicator } & \multicolumn{1}{|c|}{ Result } \\
\hline Availability of working tools & $\begin{array}{l}\text { 1. Lack of facilities and infrastructure in } \\
\text { Madang Suku II district, especially } \\
\text { computer equipment and printers. } \\
\text { 2. There is no budget available for printing } \\
\text { IUMK blanks in all districts. } \\
\text { 3. The absence of internet networks in the } \\
\text { Districts of Madang Suku II and Buay } \\
\text { Madang, so that they still rely on back- } \\
\text { up from the Office of Cooperatives and } \\
\text { SMEs in uploading data }\end{array}$ \\
\hline
\end{tabular}




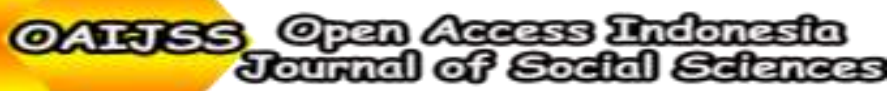

\begin{tabular}{|c|c|}
\hline Availability of human resources & $\begin{array}{l}\text { 1. The number of IUMK operators is still } \\
\text { lacking, there is only one operator in } \\
\text { each district. } \\
\text { 2. All IUMK operators are non-PNS } \\
\text { honorarium employees } \\
\text { 3. The IUMK operator's honorarium has } \\
\text { not been budgeted }\end{array}$ \\
\hline & $\begin{array}{l}\text { 1. Internal and external communication of } \\
\text { the sub-district is still lacking. } \\
\text { 2. There are still PUMK who do not } \\
\text { understand the IUMK implementation } \\
\text { program in the sub-district. }\end{array}$ \\
\hline
\end{tabular}

The dimensions of the desired performance and impact realization consists of 2 (two) indicators, namely a) the performance of the sub-district in the implementation of IUMK, and b) the impact felt by PUMK in the implementation of IUMK.

\begin{tabular}{|c|c|}
\hline Indicator & Result \\
\hline $\begin{array}{l}\text { Sub-district performance } \\
\text { implementing IUMK }\end{array}$ & $\begin{array}{l}\text { 1. An increase in IUMK ownership } \\
\text { 2. There has not been any } \\
\text { synchronization of data on the } \\
\text { implementation of IUMK in the field } \\
\text { with the website }\end{array}$ \\
\hline $\begin{array}{l}\text { The impact felt by PUMK in the } \\
\text { implementation of IUMK }\end{array}$ & $\begin{array}{l}\text { 1. Simple, easy and fast IUMK services } \\
\text { have been realized. } \\
\text { 2. Low accountability of sub-district } \\
\text { officials in the eyes of business } \\
\text { actors, because there are still costs in } \\
\text { the management of IUMK. }\end{array}$ \\
\hline
\end{tabular}




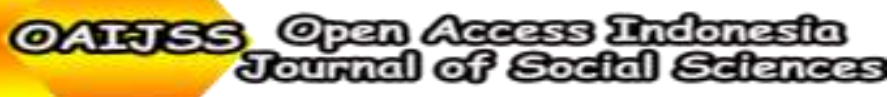

3. PUMK data has been used for invitation purposes

Supporting factors in the implementation of Regents Regulation Number 17 of 2015 concerning Technical Guidelines for the Implementation of Micro and Small Business Permits that were encountered, were socialization and ball pick-up business, efforts to fulfil service deadlines. While the inhibiting factors are the unavailability of the budget, the lack of facilities and infrastructure, the uneven distribution of networks and internet connections and the lack of coordination between agencies. Factors that support the successful implementation of District Head Regulations Number 17 of 2015 concerning Technical Guidelines for the Implementation of Micro and Small Business Permits in three sub-districts in East OKU Regency are: business licensing. The effort to fulfil the service deadline according to the determined target is one of the efforts in creating a good service function. Factors hampering the successful implementation of District Head Regulation No. 17 of 2015 concerning Technical Guidelines for the Implementation of Micro and Small Business Permits in three sub-districts in East OKU Regency are: The unavailability of the budget, so the sub-district government has difficulty in overcoming various obstacles that arise in the implementation of IUMK. The lack of facilities and infrastructure, such as computers and printers, makes it difficult in the process of typing and printing IUMK. The unequal network and internet connection in several sub-districts in East OKU Regency has hampered the real-time IUMK implementation process and the upload process of IUMK publishing data to the available pages. Lack of coordination from the Cooperative and SME Office of East OKU Regency as the leading sector to other agencies that can support monitoring and evaluation of the implementation of micro and small business permit issuance activities, such as the Regional Inspectorate of East OKU Regency, as one of the supervisory functions.

\section{Conclusion}

From the discussion above it can be concluded that the implementation of Regent's Regulation Number 17 of 2015 concerning Technical Guidelines for the Implementation of Micro and Small Business Permits in three sub-districts in East OKU Regency has not been 


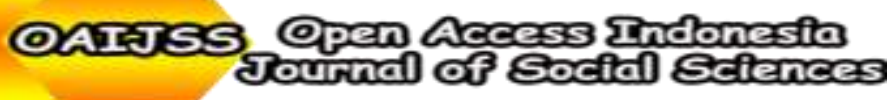

successful in terms of the dimensions of compliance, smoothness of routine functions and desired performance and impact. However, several things have been done well, as seen from the availability of the PUMK database obtained from the issuance of IUMK, as well as the number of IUMK publications in East OKU Regency which is the most in South Sumatra, which is 2,698 IUMK as of July 2017.

\section{References}

Al Fatih, Andy. 2010. Implementasi Kebijakan dan Pemberdayaan Masyarakat (Kajian pada Implementasi Program Kemitraan dalam rangka Memberdayakan Usaha Kecil. Bandung: Unpad Press.

Alkib, H. 2010. Implementasi Kebijakan: Apa, Mengapa dan Bagaimana. Jurnal Administrasi Publik. Volume 1 (1): 1-11

Anderson, James. E. 2003. Public Policymaking: an Introduction. Boston: Houghton.

Creswell, John. W. 2016. Research Design: Pendekatan Metode Kualitatif, Kuantitatif dan Campuran. Yogyakarta: Pustaka Pelajar.

Dunn, William. N. 2003. Pengantar Analisis Kebijakan Publik. Yogyakarta: Gadjah Mada Press.

Dye, Thomas. R. 2013. Understanding Public Policy. 14th Ed. USA: Pearson Education, Inc.

Edward III, G.C. 1980. Implementing Public Policy. United States of America: Congressional Quarterly Press.

Eniola, Anthony Abiodun\&Dr. Harry Entebang.2015.Government Policy and Performance of Small and Medium Business Management. International Journal of Academic Research in Business and Social Sciences, February 2015, Vol. 5, No. 2

Grindle, Merilee. S. 1980. Politcs and Policy Impementation in the Third World.Princeton NJ: Princeton University Press.

Hayubi, Ghanda. 2016. Pemberian Izin Gangguan/ HO (Hinder Ordonantie) Usaha Bengkel Sepeda Motor di Kecamatan Lubuk Kilangan Kota Padang. Skripsi. Universitas Andalas: Padang. 


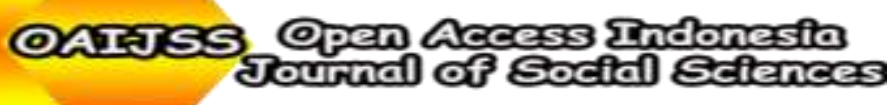

Jahanshahi, Asghar Afshar et all.2011.The Relationship between Government Policy and the Growth of Entrepreneurship in the Micro, Small \& Medium Enterprises of India. Journal of Technology Management \& Innovation, Volume 6 Issue I.

Julita, Ami. 2017. Pelaksanaan IUMK Gratis di Kecamatan Sukajadi Kota Pekanbaru. Jurnal JOM Fisip. Vol.4. No.1 Februari 2017.

Mazmanian, Daniel A.\&Paul A. Sabatier.1983. Implementation and Public Policy. New York: Harpercollins.

Meter, D.S.Van\&C.E.Van Horn. 1975. The Policy Implementation Process: A Conceptual Framework. Administration and Society Journal, Vol. 6. No.4 (p. 445-448).

Moleong, Lexy J. 2004. Metode Penelitian Kualitatif. Bandung: PT. Remaja Rosdakarya

Nadela, Ayu Lestari. 2017. Penerapan IUMK di Kecamatan Tampan Pekanbaru. Jurnal JOM Fisip. Vol.4. No.2 Oktober 2017.

Nugroho, Riant. 2014. Public Policy: Teori, Manajemen, Dinamika, Analisis, Konvergensi, dan Kimia Kebijakan. Jakarta: PT. Elex Media Komputindo.

Nugroho, Sulistiyo Ardi. 2016. Reformasi Administrasi Pelayanan Publik (Studi PATEN Jawa Tengah). Gema Publika. Vol.2. No.1 Maret 2016.

Peraturan Bupati OKU Timur Nomor 17 tahun 2015 tentang Petunjuk Teknis Pelaksanaan Izin Usaha Mikro dan Kecil kepada Camat.

Peraturan Daerah (Perda) Nomor 27 Tahun 2003 Seri C Tentang Surat Izin Usaha Perdagangan (SIUP) (Suatu Studi Tentang Perkembangan Usaha Mikro Kecil Menengah (UMKM) di Kota Cimahi). Majalah Ilmiah UNIKOM. Vol.11. No.1

Peraturan Menteri Dalam Negeri Nomor 83 tahun 2014 tentang Pedoman Pemberian Izin Usaha Mikro dan Kecil.

Peraturan Presiden Nomor 98 tahun 2014 tentang Perizinan untuk Usaha Mikro dan Kecil.

Raselawati, Ade. 2011. Pengaruh Perkembangan Usaha Kecil Menengah terhadap Pertumbuhan Ekonomi Pada Sektor UKM di Indonesia. Skripsi. Universitas Syarif Hidayatullah: Jakarta

Richardson, P, Howarth, R and Finnegan, G. 2004. The Challenges of Growing Small Businesses: Insights from Women Entrepreneurs in Africa, ILO, Genevea.

Ripley, Randall. B. dan Grace A. Franklin. 1986. Policy Implementation and Bureaucracy. Chicago:The Dorsey Press.

Saputra, Adi Darma. 2015. Implementasi Kebijakan Usaha Mikro Kecil dan Menengah 


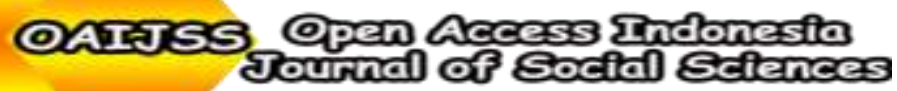

(UMKM) di Kecamatan Pontianak Timur. Jurnal PublikA volume 4 nomor 1 tahun 2015. Supriyanto. 2006. Pemberdayaan Usaha Mikro, Kecil dan Menengah (UMKM) sebagai Salah

Satu Upaya Penanggulangan Kemiskinan. Jurnal Ekonomi dan Pendidikan Volume 2 Tahun 2006.

Thoha, Miftah. 2008. Ilmu Administrasi Publik Kontemporer. Jakarta: Kencana.

Undang-undang Nomor 20 Tahun 2008 tentang Usaha Mikro, Kecil dan Menengah.

Weaver, R.K. 2009. Target Compliance: The Final Frontier of Policy Implementation. Issues in Governence Studies: Volume 27: 1-11. 